\title{
Discoloration and Decay in Severed Tree Roots
}

\author{
Gary Watson
}

\begin{abstract}
Roots of honeylocust (Gleditsia triacanthos var. inermis), pin oak (Quercus palustris), tuliptree (Liriodendron tulipifera), and green ash (Fraxinus pennsylvanica) trees were severed at the root flare and 1, 2, or $3 \mathrm{~m}(3.3,6.6$, and $9.9 \mathrm{ft})$ from the trunk. After 5 years, the severed roots were excavated and all discolored and decayed portions were removed. The furthest extent of decay development ranged between $4.5 \mathrm{~cm}(1.8 \mathrm{in})$ in green ash and $10.8 \mathrm{~cm}(4.3 \mathrm{in})$ in honeylocust. The furthest extent of discoloration also varied between $6.3 \mathrm{~cm}(2.5 \mathrm{in})$ in green ash and $77.1 \mathrm{~cm}(30.8 \mathrm{in})$ in honeylocust. The root severing location producing the greatest decay or discoloration varied among species. Natural defect development as a result of severing roots of any size root at any distance is not likely to result in a threat to the health or stability of a tree.

Key Words. Compartmentalization; defect; Fraxinus pennsylvanica; Gleditsia triacanthos var. inermis; Liriodendron tulipifera; Quercus palustris; root severing.
\end{abstract}

Root injury is common in urban trees. Nursery production, transplanting, construction activity, and utility installation frequently result in root injury. Introduction of extensive discoloration and decay defects through injury to tree trunks and branches is well known by arborists. This awareness has led to widespread concern that similar mechanical root injury can introduce extensive decay into tree root systems and that it could eventually spread to the trunk and lead to major tree health and stability problems.

Even in nature, without human activity, root injury is common. Formation of lateral roots creates injury when outer layers of cells (endodermis, cortex, and epidermis) are ruptured as the new root emerges from the pericycle layer in the interior of the root where it is initiated (Esau 1960). Insects, compression, animal trampling, excessive moisture, abrasion against stone surfaces, breakage of small laterals by movement resulting from frost heaving and the root plate rocking in the wind, and dieback response to root stress or root disease all produce injuries to roots (Redmond 1957; Whitney 1961; Stone 1977; James et al. 1980). Root dieback can also result from crown stresses such as defoliation (Redmond 1957). When secondary roots die, they leave natural openings that can act as infection courts for decay fungi (Redmond 1957; Shigo 1979b; Robinson and Morrison 2001).

Discoloration and decay are the principal defects associated with injuries to trees (Shigo 1991). Wood discoloration is caused by invasion of bacteria and nonhymenomycetous fungi. The discolored wood area is often larger than pathogen-colonized area (Shigo and Hillis 1973; Garboletto et al. 1997).

Compartmentalization Of Decay In Trees (CODIT; Shigo 1977) principles apply to roots as well as stems (Shigo 1972; Shigo 1979b; Tippett and Shigo 1981; White and Kile 1993; Robinson and Morrison 2001), although roots have not been as extensively studied. Because root injuries are common, and injuries serve as infection courts for root-rotting organisms (Tippett et al. 1982), roots have evolved to be strong compartmentalizers (Shigo 1986). Dead roots are of less significance than dead tops in providing courts of entry for decay (Redmond 1957).

There is evidence that decay of root wood blocks is greater than stems in laboratory tests and was attributed to higher nitro- gen and carbohydrates (Platt et al. 1965). Rate of decay development in live roots after inoculation with root rot fungi is slower than in stems and may reflect the higher proportion of living cells in roots (White and Kile 1993).

Literature reports on rates of root wood decay development are dominated by inoculation experiments with aggressive root rotting fungi such as Heterobasidium annosum and Armillaria mellea on commercially valuable conifers. In nature, it is unlikely for wood to be decomposed completely by one organism (Shigo 1967).

Average values of longitudinal extension of decay columns after inoculation have been reported from 10 to $53 \mathrm{~cm} / \mathrm{yr}^{-1}$ (4 to $21 \mathrm{in} / \mathrm{yr}^{-1}$ ) (White and Kile 1993; Morrison and Redfern 1994; Garboletto et al. 1997; Piri 1998). Colonization often progresses faster in the proximal direction (toward the stem) from the wound (Yokota 1962; Shigo 1979b; Garboletto et al. 1997). Decay introduced experimentally through root wounds within a meter of the trunk can extend into the trunk (Redmond 1957; Garboletto et al. 1997). In one report, trunk wood discoloration and decay were observed only when the root cambium had died back to, or above, the soil surface (Santamour 1985).

Colonization rate can be increased by drought stress (Towers and Stambaugh 1968; Lindberg and Johansson 1992). Fertilization has been reported to both increase (Piri 1998) and decrease (Singh 1983) decay fungal colonization. Stimulation or inhibition of decay fungus colonization by stress seems to be dependent on level of the stress factor as well as host and pathogen species (Wahlstrom and Barklund 1994; Desprez-Loustau et al. 2006).

Root size and proximity to the trunk has been reported to affect decay development rate. Root decay increased as root size increased on hardwoods (Whitney 1967; Santamour 1985; Balder et al. 1995) and conifers (Garboletto et al. 1997; Piri 1998; Tian and Ostrofsky 2007). Injury to roots closer to the trunk resulted in more extensive defects on hardwoods (Balder et al. 1995).

In the only previous study of defect development after wounding roots of landscape trees, roots of 7-year-old sweetgum ( $\mathrm{Li}$ quidambar orientalis $\times$ L. styraciflua) and plane hybrids (Plata- 
nus occidentalis $\times P$. orientalis) were severed by simulated digging and harvested 4 years later. There was no decay or discoloration in the trunk from root severing and no decay more than $7 \mathrm{~cm}$ (2.8 in) from the cut (Santamour 1985).

Santamour (1985) also reported differences between species in their ability to resist trunk decay and discoloration after root severance. Four years after severing roots within $0.5 \mathrm{~m}(1.7 \mathrm{ft})$ of the trunk, there was no discoloration or decay in trunk tissues in red maples (Acer rubrum) and $6 \mathrm{~cm}$ (2.4 in) maximum in the roots. Discoloration and decay were present in trunk tissues of two of ten black oaks (Quercus velutina) and four of ten white oaks $(Q$. alba) after similar root severance. All of these individual trees were weak Wall 2 compartmentalizers, but not all weak Wall 2 compartmentalizers developed discoloration and decay in trunk tissues.

The objective of this study was to investigate whether severing deciduous hardwood tree roots of any size or at distance from the trunk could lead to defect development that could threaten the health or stability of the tree.

\section{METHODS}

The trees available for this study were planted as blocks of seedlings in 1956 on an Askum silty clay loam soil at the Morton Arboretum in northern Illinois, U.S. Supplemental irrigation was not provided at any time after the plot was established. Four species of trees included in the study were honeylocust (Gleditsia triacanthos var. inermis), pin oak (Quercus palustris), tuliptree (Liriodendron tulipifera), and green ash (Fraxinus pennsylvanica). The individual trees selected for this study were the more vigorous individuals in a moderately crowded block $(4.5 \mathrm{~m}$ [14.9 ft] centers). All exhibited typical twig growth for healthy trees of their species and age. Average diameter at breast height of trees used in the study was $30,30.7,35.4$, and $34.3 \mathrm{~cm}(12$, $12.3,14.2$, and $13.7 \mathrm{in})$, respectively.

Roots were severed at four distances from the trunk in November 1998: on the root flare where the root becomes visible at the soil surface and 1,2 , or $3 \mathrm{~m}(3.3,6.6$, and $9.9 \mathrm{ft})$ from the trunk. Roots were traced to the appropriate distance without excavating using a tile probe. All roots were no more than $30 \mathrm{~cm}$ (12 in) deep. There were five roots severed at each distance. In most cases, different roots were severed at each of the four distances on a single tree. Occasionally, when not enough roots could be found on a single tree, a second nearby tree had to be used to complete the set, most often for the root flare cut. No roots could be successfully traced to $3 \mathrm{~m}(9.9 \mathrm{ft})$ on pin oaks because of the small diameter of the roots of this species.

A chain saw with carbide teeth was used to cut the flare root. A stump grinder was used at the other three distances. The diameter of the severed root end was measured from the face of the cut. Two perpendicular diameter measurements were averaged. To facilitate finding the roots later, locations of the cut roots were mapped and a steel nail was buried approximately 10 $\mathrm{cm}$ (4 in) below grade to mark the exact location of the severed root end. Root wounds were exposed to natural decay fungi present in the soil, but no inoculations were performed.

After 5 years, the severed ends of the roots were relocated using the maps and a metal detector. All discolored and decayed portions of the cut roots were excavated with an air tool and removed. The excavated roots were cut into sections. The first 10 $\mathrm{cm}$ (4 in) was split longitudinally and sanded to measure the extent of discoloration and decay. If discoloration and decay extended beyond the first $10 \mathrm{~cm}$ (4 in), additional $5 \mathrm{~cm}$ (2 in) sections were cut and sanded until discoloration and decay were no longer present in the cross-section.

The cross-section of the stump (approximately 10 to $15 \mathrm{~cm}$ [4 to 6 in] above grade) was examined when the tree was cut down. If any discoloration was present, additional cross-sections of the trunk were cut at $30 \mathrm{~cm}$ (12 in) intervals until discoloration was no longer visible. Stumps were excavated and a longitudinal section of the severed flare root was removed with a chain saw and sanded smooth.

Discoloration was quantified by measuring the proximal extent of visibly discolored wood from the severed root end. Decay in living trees has been described as a softening or weakening of the woody xylem tissues (Hartman et al. 2000). Methods used in similar situations have involved noting color change (Whitney 1997) along with simple techniques to estimate mechanical resistance such as probing with a sharp object (Tokuda et al. 2007) or drilling (Costello and Quarles 1999; Fraedrich and Smiley 2002). A similar method of detecting decayed wood in the dissected roots was devised using change in color and mechanical resistance of the wood tissue on the longitudinal sections of roots. The sample was placed on a Homs Model 40 spring scale (Douglas Homs Corp., Belmont, CA) and a blunt dissecting needle was pressed into the wood until the scale read $1.8 \mathrm{~kg}$ (4 lbs) to develop consistent pressure each time. In unaffected and discolored wood, the depression made by the blunt tip was barely detectable. At the border between discolored and decayed wood (identifiable by color change), the tip abruptly began to penetrate deeper. When the tip penetrated more than $1 \mathrm{~mm}(0.04 \mathrm{in})$, the wood was considered decayed. The transition zone was always less than $10 \mathrm{~mm}(0.4 \mathrm{in})$ and often less than $5 \mathrm{~mm}(0.2 \mathrm{in})$. The extent of decayed wood from the severed end was recorded. If some wood had completely decayed away, the position of the original cut was estimated as accurately as possible from the new sound wood formed around the decayed wood. This method was much more precise than $5 \mathrm{~cm}$ ( 2 in) resolution obtained by methods using culture and identification of decay fungi (Lindberg and Johansson 1992; Garboletto et al. 1997).

Each species was considered a separate experiment. One-way analysis of variance $(P \leq 0.05)$, with separation of means by the Student-Newman-Keuls Method (SigmaStat 3.0; SPSS Science, Chicago, IL) was used to compare extent of discoloration and decay among root-severing distances.

\section{RESULTS AND DISCUSSION}

After 5 years, the furthest extent of decay development ranged between $4.5 \mathrm{~cm}$ (1.8 in) in green ash and $10.8 \mathrm{~cm}$ (4.3 in) in honeylocust. The furthest extent of discoloration development also varied from $6.3 \mathrm{~cm}$ (2.5 in) in green ash to $77.1 \mathrm{~cm}$ (30.8 in) in honeylocust. Typical examples are shown in Figure 1. The cut location with the greatest decay or discoloration varied widely among species (Table 1).

The annual rate of decay development was very slow at 0.9 to $2.2 \mathrm{~cm} / \mathrm{yr}^{-1}$ (0.4 to $\left.0.9 \mathrm{in} / \mathrm{yr}^{-1}\right)$, compared with rates of 10 to 53 $\mathrm{cm} / \mathrm{yr}^{-1}$ (4 to $21.2 \mathrm{in} / \mathrm{yr}^{-1}$ ) reported after inoculation of aggressive root rot fungi in conifers (White and Kile 1993; Morrison and Redfern 1994; Garboletto et al. 1997; Piri 1998). Santamour (1985) observed an even slower maximum rate of decay progression of $1.5 \mathrm{~cm} / \mathrm{yr}^{-1}\left(0.6 \mathrm{in} / \mathrm{yr}^{-1}\right)$ resulting from natural infection in response to severing roots of hardwoods $0.5 \mathrm{~m}(1.7 \mathrm{ft})$ from the trunk and also with variation in species response. 


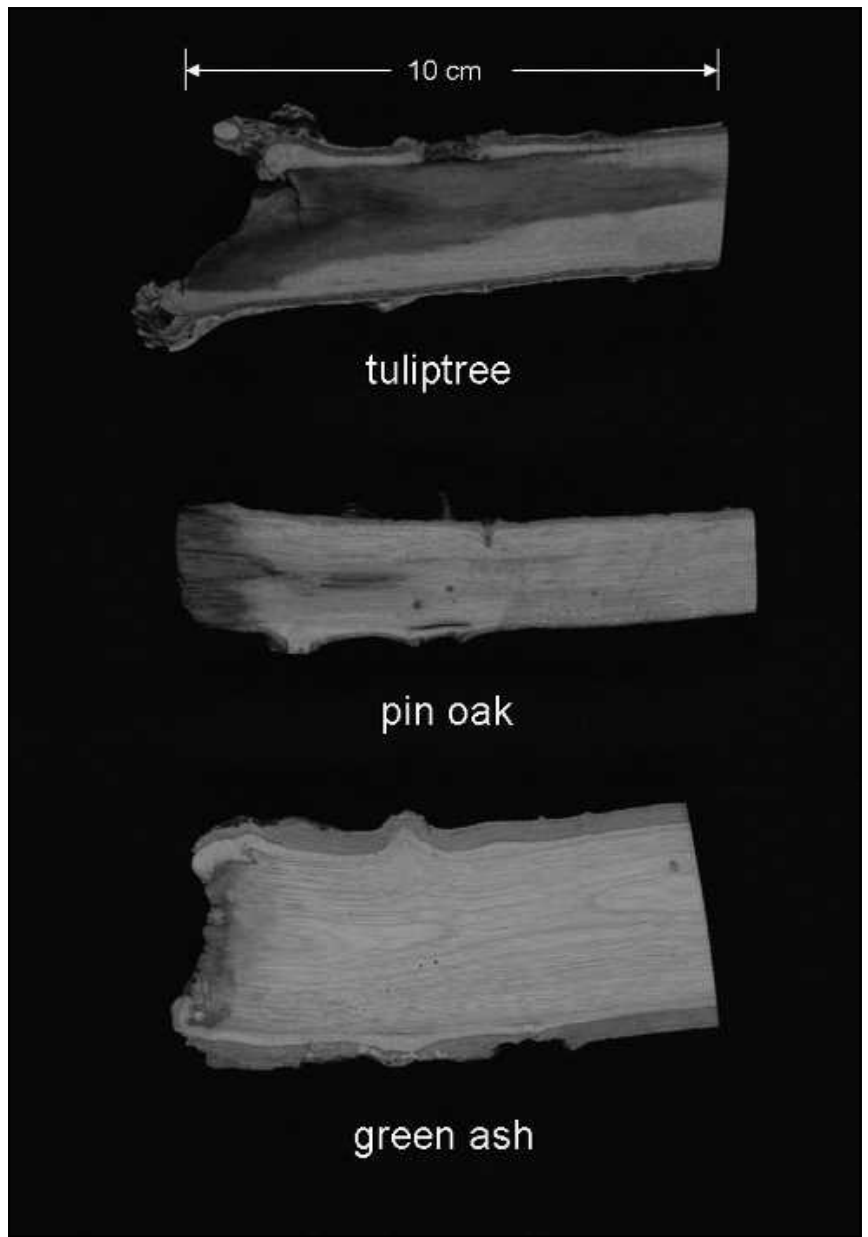

Figure 1. Typical discoloration and decay from severing roots.

Root injury close to the trunk would pose the greatest threat for development of basal defects that would threaten tree stability and health. Wounds inflicted at the base of the trunk have been found to be resistant to decay (Shigo 1991). Decay extended a short distance from the root flare cuts into the root flare wood $(10.3 \mathrm{~cm}$ [4.1 in] maximum in tuliptree), but it never extended into trunk wood (stump cut) on any tree. A small discoloration streak in the outermost wood present at the time of the flare cut did sometimes extend into the base of the trunk (stump cut or beyond) in three of the four species (Figure 2). In the CODIT model, Wall 1 directly above and below the wound is the weakest. The discoloration was never more than a few square centimeters (less than a square inch) in the cross-sectional area. Santamour (1985) reported discoloration and decay in the trunk only when there was cambium dieback to or beyond the root flare after roots were severed a half meter from the trunk. In our study, the flare roots were damaged directly and cambium dieback was unnecessary for discoloration to progress into trunk wood.

Defects never penetrated the stronger Wall 2 (Shigo 1977) and developed toward the center of the trunk. There was no indication that even such a severe wound at the base of the trunk would routinely lead to deterioration in health or stability of any of these species. The data from this study do not agree with an earlier report describing root flare injury as causing extensive columns of decay in the trunk (Shigo 1979a).

Defects resulting from any of the more distant cuts never extended into the root flare or trunk wood. When roots were cut $1 \mathrm{~m}(3.3 \mathrm{ft})$ from the trunk, discoloration never extended closer than $70 \mathrm{~cm}$ (28 in) to the trunk in honeylocust. The distance was even greater for the other species. More distant cuts resulted in even greater separation between the defect development and the trunk. Root injury $1 \mathrm{~m}(3.3 \mathrm{ft})$ or more from the trunk does not seem to be a cause of decay in the major roots or trunk.

To investigate the effect of root size on discoloration and decay, roots of each species were grouped into $5 \mathrm{~cm}$ (2 in) size classes. The diameter of the severed roots had no effect, except that discoloration was greater on pin oak and tuliptree roots larger than $10 \mathrm{~cm}$ (4 in) diameter (data not shown). All of these larger roots were flare cut roots, and the large root flare cuts developed significantly more decay than the other locations in pin oak (Table 1). The difference may have been attributable as much to location as to size. Balder et al. (1995) reported that injury to both larger roots and roots closer to the trunk resulted in more extensive defects.

Roots were injured in November, when dormant, and potentially the time of year most conducive to discoloration and decay development. Balder et al. (1995) reported that injuries of oak and linden roots in winter lead to poorer compartmentalization than injuries at the beginning of the season. Santamour (1985) reported no difference between groups of sweetgums and planetrees dug during the dormant and growing seasons.

Table 1. Average severed root diameter and extent of discoloration and decay defects in roots of four different species severed at four distances from the trunk. ${ }^{2}$

\begin{tabular}{|c|c|c|c|}
\hline & $\begin{array}{l}\text { Diameter of } \\
\text { severed root } \\
(\mathrm{mm})\end{array}$ & $\begin{array}{l}\text { Average extent } \\
\text { of decay } \\
(\mathrm{cm})^{\mathrm{y}}\end{array}$ & $\begin{array}{l}\text { Average extent } \\
\text { of discoloration } \\
(\mathrm{cm})^{\mathrm{y}}\end{array}$ \\
\hline \multicolumn{4}{|c|}{ Green ash } \\
\hline Flare & 17.8 & $1.0 \mathrm{a}$ & $3.2 \mathrm{a}$ \\
\hline $1 \mathrm{~m}$ & 4.0 & $1.5 \mathrm{a}$ & $4.2 \mathrm{a}$ \\
\hline $2 \mathrm{~m}$ & 2.3 & $1.8 \mathrm{a}$ & $7.2 \mathrm{a}$ \\
\hline $3 \mathrm{~m}$ & 3.4 & $4.5 \mathrm{a}$ & $6.3 \mathrm{a}$ \\
\hline \multicolumn{4}{|c|}{ Honeylocust } \\
\hline Flare & 12.0 & $3.6 \mathrm{a}$ & $35.1 \mathrm{~b}$ \\
\hline $1 \mathrm{~m}$ & 6.6 & $10.8 \mathrm{a}$ & $30.1 \mathrm{~b}$ \\
\hline $2 \mathrm{~m}$ & 4.4 & $6.4 \mathrm{a}$ & $58.3 \mathrm{ab}$ \\
\hline $3 \mathrm{~m}$ & 3.5 & $4.5 \mathrm{a}$ & $77.1 \mathrm{a}$ \\
\hline \multicolumn{4}{|l|}{ Pin oak } \\
\hline Flare & 22.0 & $6.5 \mathrm{a}$ & $43.9 \mathrm{a}$ \\
\hline $1 \mathrm{~m}$ & 3.5 & $1.0 \mathrm{~b}$ & $14.0 \mathrm{~b}$ \\
\hline $2 \mathrm{~m}$ & 2.4 & $2.2 \mathrm{~b}$ & $13.3 \mathrm{~b}$ \\
\hline $3 \mathrm{~m}$ & - & - & - \\
\hline \multicolumn{4}{|l|}{ Tuliptree } \\
\hline Flare & 17.1 & $10.3 \mathrm{a}$ & $68.9 \mathrm{a}$ \\
\hline $1 \mathrm{~m}$ & 6.1 & $4.4 \mathrm{a}$ & $15.3 \mathrm{~b}$ \\
\hline $2 \mathrm{~m}$ & 3.4 & $3.6 \mathrm{a}$ & $11.3 \mathrm{~b}$ \\
\hline $3 \mathrm{~m}$ & 2.5 & $6.9 \mathrm{a}$ & $10.6 \mathrm{~b}$ \\
\hline
\end{tabular}

${ }^{\mathrm{z}}$ Each value is the average of five replications.

${ }^{\mathrm{y}}$ For each species, values in the same column followed by the same letter are not significantly different at $P \leq 0.05$. 


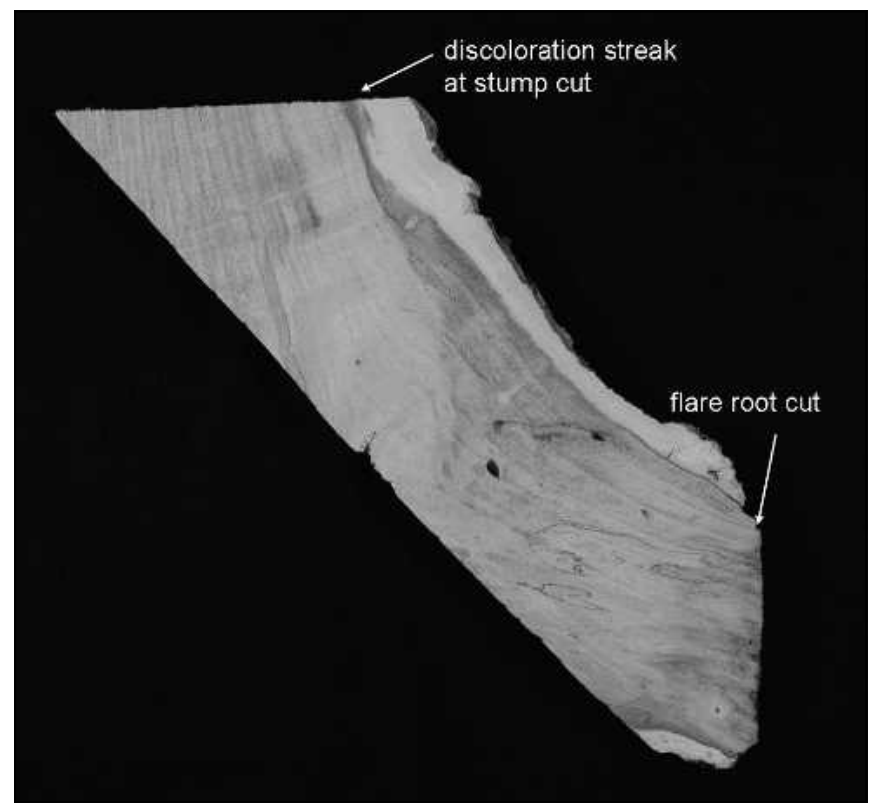

Figure 2. Example of discoloration and decay pattern from root flare cut. Discoloration in trunk wood was never more than a small streak.

\section{CONCLUSIONS}

Roots are good compartmentalizers. Severed roots of all sizes, located throughout the root system, showed only minimal discoloration and decay defects after 5 years. In these four species, there is minimal risk of introducing serious decay through injury of tree roots. Unlike branches, in which leaving a stub can lead to more extensive decay, "leaving a root stub" did not result in substantial decay and deterioration of the roots.

A 5-year study may not be entirely conclusive but does give a strong indication that root injury does not typically lead to extensive basal decay in trees. Based on the rate of decay observed in the first 5 years after severing the roots, extensive decay is not likely to develop in urban trees with a lifespan estimated at 5 to 45 years (Nowak et al. 2004). A long-term study of branch wounds showed that there was little difference in the area of discoloration between the first and ninth year after wounding (Dujesiefken and Stobbe 2002). If the same is true of roots, decay may have essentially stopped by the fifth year sampling date and pose no threat at all to the long-term health and stability of the trees.

Acknowledgments. Partial funding for this project was received from the The Care of Trees, Wheeling, Illinois.

\section{LITERATURE CITED}

Balder, V.H., D. Dujesiefken, T. Kowol, and E. Schmitz-Felten. 1995. Aspects of wound treatments of oak and basswood roots. Nachrichtenblatt des Deutschen Pflanzenschutzdienstes 47:28-35.

Costello, L.R., and S.L. Quarles. 1999. Detection of wood decay in blue gum and elm: And evaluation of the Resistograph ${ }^{\circledR}$ and the portable drill. Journal of Arboriculture 25:311-318.

Desprez-Loustau, M.-L., B. Marcais, L.-M. Nageleisen, D. Piou, and A. Vannini. 2006. Interactive effects of drought and pathogens in forest trees. Annals of Science 63:597-612.

Dujesiefken, D., and H. Stobbe. 2002. The Hamburg tree pruning system-A framework for pruning of individual trees. Urban Forestry and Urban Greening 1:75-82.
Esau, K. 1960. Anatomy of Seed Plants. Wiley, New York, NY. 376 pp. Fraedrich, B.R., and E. Thomas Smiley. 2002. Assessing the failure potential of tree roots, pp. 159-163. In: Smiley, E.T., and K.D. Coder (Eds.). Tree Structure and Mechanics Conference Proceedings: How Trees Stand Up and Fall Down. International Society of Arboriculture, Champaign, IL.

Garboletto, M., G. Slaughter, T. Popenuck, F.W. Cobb, and T.D. Bruns. 1997. Secondary spread of Heterobasidion annosum in white fir rootdisease centers. Canadian Journal of Forest Research 27:766-773.

Hartman, J.R., T.P. Pirone, and M.A. Sall. 2000. Pirone's Tree Maintenance. Oxford University Press, New York, NY. 545 pp.

James, R.L., F.W. Cobb Jr., P.R. Miller, and J.R. Parmeter Jr. 1980. Effects of oxidant air pollution on susceptibility of pine roots to Fomes annosus. Phytopathology 70:560-563.

Lindberg, M., and M. Johansson. 1992. Resistance of Picea abies seedlings to infection by Heterobasition annosum in relation to drought stress. European Journal of Forest Pathology 22:115-124.

Morrison, D.J., and D.B. Redfern. 1994. Long-term development of Heterobasition annosum in basidiospore-infected Sitka spruce stumps. Plant Pathology 43:897-906.

Nowak, D.J., M. Kuroda, and D.E. Crane. 2004. Tree mortality rates and tree population projections in Baltimore, Maryland, USA. Urban Forestry and Urban Greening 2:139-148.

Piri, T. 1998. Effects of vitality fertilization on the growth or Heterobasidion annosum in Norway spruce roots. European Journal of Forest Pathology 28:391-397.

Platt, W.D., E.B. Cowling, and C.S. Hodges. 1965. Comparative resistance of coniferous root wood and stem wood to decay by isolates of Fomes annosus. Phytopathology 55:1347-1353.

Redmond, D.R. 1957. Infection courts of butt-rotting fungi in balsam fir. Forest Science 3:15-21.

Robinson, R.M., and D.J. Morrison. 2001. Lesion formation and host response to infection by Armilaria ostoyae in the roots of western larch and Douglas-fir. Forest Pathology 31:371-385.

Santamour, F.S. Jr. 1985. Trunk wood discoloration and decay following root wounding. Journal of Arboriculture 11:257-262.

Shigo, A.L. 1967. Successions of organisms in discoloration and decay of wood. International Review of Forestry Research 2:237-299.

. 1972. Successions of microorganisms and patters of discoloration and decay after wounding in red oak and white oak. Phytopathology 62:256-259.

. 1977. Compartmentalization of Decay in Trees. USDA Forest Service Agriculture Information Bulletin Number 405. 70 pp.

. 1979a. Tree Decay: An Expanded Concept. USDA Forest Service Agriculture Information Bulletin Number 419. 72 pp.

- 1979b. Compartmentalization of decay associated with Heterobasidion annosum in roots of Pinus resinosa. European Journal of Forest Pathology 9:341-347.

1986. A New Tree Biology Dictionary. Shigo and Trees, Associates, Durham, NH. 132 pp.

1991. Modern Arboriculture. Shigo and Trees, Associates, Durham, NH. 424 pp.

Shigo, A.L., and W.E. Hillis. 1973. Heartwood, discolored wood, and microorganisms in living trees. Annual Review of Phytopathology 11:197-222.

Singh, P. 1983. Armillaria root rot: Influence of soil nutrients and $\mathrm{pH}$ on the susceptibility of conifer species to the disease. European Journal of Forest Pathology 13:92-101.

Stone, E.L. 1977. Abrasion of tree roots by rock during wind stress. Forest Science 23:333-336.

Tian, S., and W.D. Ostrofsky. 2007. Butt and root decay in precommercially thinned spruce-fir stands. Northern Journal of Applied Forestry 24:129-133.

Tippett, J.T., and A.L. Shigo. 1981. Barriers to decay in conifer roots. European Journal of Forest Pathology 11:51-59. 
Tippett, J.T., A.L. Bogle, and A.L. Shigo. 1982. Response of balsam fir and hemlock roots to injuries. European Journal of Forest Pathology 12:357-364.

Tokuda, S., Y. Ota, and T. Hattori. 2007. Root and butt rot of Todo fir (Abies sachalinensis) caused by Heterobasidion annosum s.1. in Hokkaido, Japan. Forest Pathology 37:155-166.

Towers, B., and W.J. Stambaugh. 1968. The influence of induced soil moisture stress upon Fomes annosus root rot of loblolly pine. Phytopathology 58:269-272.

Wahlstrom, K.T., and P. Barklund. 1994. Spread of Armillarioa spp. and Heterobasidion annosum in Norway spruce exposed to drought, irrigation and fertilization, pp. 582-591. In: Johansson, M., and J. Stenlid (Eds.). Proceedings of the 8th International Conference on Root and Butt Rots. Swedish University of Agricultural Sciences, Uppsala.

White, D.A., and G.A. Kile. 1993. Discolouration and decay from artificial wounds in 20-year-old Eucalyptus regnans. European Journal of Forest Pathology 23:431-440.

Whitney, R.D. 1961. Root wounds and associated root rots of white spruce. Forestry Chronicle 37:401-411.

. 1967. Comparative susceptibility of large and small spruce roots to Polyporous tomentosus. Canadian Journal of Botany 45: 2227-2229.

- 1997. Relationship between decayed roots and aboveground decay in three conifers in Ontario. Canadian Journal of Forest Research 27:1217-1221.

Yokota, S. 1962. Wood decay of Abies sachalinensis forest in the Tokyo University Forest, Hokkaido. IV. Inoculation Experiment on Living Root with Fomitopsis annosa (Fr.) Karst. Bulletin of the Tokyo University Forests 56:335-348.

\section{Gary Watson}

The Morton Arboretum

4100 Illinois Route 53

Lisle, IL 60532, U.S.

gwatson@mortonarb.org

Résumé. Les racines de féviersinerme (Gleditsia triacanthos var. inermis), de chêne des marais (Quercus palustris), de tulipier de Virginie (Liriodendron tulipifera) et de frêne de Pennsylvanie (Fraxinus penn- sylvanica) ont été cernées à 1,2 et $3 \mathrm{~m}$ de distance du tronc. Après cinq ans, toutes les parties contenant du bois décoloré ou carié provenant des racines coupées ont été excavées et recueillies. La plus grande étendue de carie provenant de n'importe quelle coupe faite variait de moins de 5 $\mathrm{cm}$ de distance (depuis la surface de coupe) pour le frêne de Pennsylvanie à un peu moins de $11 \mathrm{~cm}$ dans le cas du tulipier de Virginie et du févier inerme. L'étendue de bois décoloré était plus grande que celle du bois carié pour toutes les espèces, allant jusqu'à $50 \mathrm{~cm}$ de distance sauf dans le cas du frêne. Les coupes en biais de racines, qui étaient aussi les plus grosse racines coupées, produisaient plus de bois décoloré et de bois carié à n'importe quel endroit chez le chêne des marais, et plus de bois décoloré chez le tulipier de Virginie, mais pas dans le cas du frêne de Pennsylvanie et du févier inerme. Dans tous les cas, la carie était limitée à de petites poches et n'affectait pas réellement la santé ou la stabilité de l'arbre.

Zusammenfassung. Die Wurzeln von Gleditschie, Pin-Eiche, Tulpenbaum und Grüner Esche wurden in 1, 2 oder $3 \mathrm{~m}$ Abstand vom Baum gekappt. Nach fünf Jahren wurden alle verfärbten und verfaulten Wurzelteile ausgegraben und entfernt. Der weiteste Abstand der Fäule zur Schnittkante betrug weniger als $5 \mathrm{~cm}$ bei der Esche und ca. $11 \mathrm{~cm}$ bei der Gleditschie und dem Tulpenbaum. Die weiteste Ausdehnung von Verfärbungen war in allen Spezies größer als die Fäule und betrug ohne die Esche ca. $50 \mathrm{~cm}$. Weite Schnitte, die auch die größten Wurzelschnitte darstellten, verursachten an jeder Stelle größere Verfärbung und Fäule bei der Eiche und größere Verfärbung bei den Tulpenbäumen, aber nicht bei den Eschen und Gleditschien. In allen Fällen war die Fäule auf schmale Taschen begrenzt und konnte die Gesundheit oder Stabilität der Bäume nicht beeinflussen.

Resumen. Las raíces de árboles de acacia (Gleditsia triacanthos var. inermis), encino (Quercus palustris), tulipan (Liriodendron tulipifera) y encino (Fraxinus pennsylvanica) fueron cortadas a 1, 2 y $3 \mathrm{~m}$ del tronco. Después de 5 años todas las porciones decoloradas y decaídas de las raíces cortadas fueron excavadas y removidas. La porción descompuesta en todos los árboles fue menor de $5 \mathrm{~cm}$ en fresno a levemente menor a $11 \mathrm{~cm}$ en tulipán y acacia. La extensión de la decoloración fue mayor que el decaimiento en todas las especies, excediendo $50 \mathrm{~cm}$ en todos menos en fresno. Los cortes en la corona de la raíz, lo cuales fueron también las cortas más grandes, produjeron mayor decoloración y decaimiento en los encinos, y también en el tulipán, pero no en fresno y acacia. En todos los casos, el decaimiento estuvo limitado a pequeñas bolsas y no pareció amenazar la salud y estabilidad e los árboles. 